\title{
Effect of foliar application of some vitamins and irrigation intervals on vegetative growth, flowering, and some biochemical constituents of Helianthus annuus $L$. plants.
}

\author{
Naglaa M. Mostafa \\ Ornamental Plants \& Landscape Gardening Research Department, Horticulture Research Institute, ARC, \\ Alexandria, Egypt. \\ Corresponding author email: dr.naglaamoh@gmail.com
}

Received on: 5/11/2020

Accepted on: 28/11/2020

\begin{abstract}
A pot experiment was conducted during the seasons of 2017 and 2018 at Antoniades Research Branch, Horticulture Research Institute, A.R.C. Alexandria, Egypt to study the effects of foliar spray of some vitamins (control, ascorbic acid, $\alpha$-tocopherol or nicotinamide) at $100 \mathrm{ppm}$ and irrigation intervals ( 2 or 3 days) on the vegetative growth, flowering, and some biochemical constituents of (Helianthus annuus L.) plants. The results cleared that, most parameters were significantly affected by application of the three vitamins which were used in this study. The magnitude of increase is more pronounced by applying $\alpha$-tocopherol, where, using $\alpha$-tocopherol by $100 \mathrm{ppm}$ gave the highest number of leaves and stem diameter, and the lowest proline concentration. Also, using of $\alpha$-tocopherol by 100 ppm combined with 3 days irrigation interval gave the highest significant increases in the plant height, leaf area, leaves dry weight, stem dry weight, flower duration, flower dry weight, and leaves content of chlorophyll a, chlorophyll b and total carbohydrate.
\end{abstract}

KEYWORDS: Helianthus annuus L. - ascorbic acid - $\alpha$-tocopherol - nicotinaide - irrigation intervals.

\section{INTRODUCTION}

Sunflower (Helianthus annuus L.) plant is a member of family Asteraceae. Its native origin is North America. It has been used in gardens as an ornamental plant for several years (Kirtimala et al, 2018). The beauty of its inflorescence, the possibility of using it as a cut flower increased its value in the flower and ornamental plant markets. (Cormenzana, 2001).

Water requirement is the most important factor that effect on the yield of sunflower. Kakar and Soomro (2001) found that increasing irrigation intervals caused a reduction in plant height, seed yield, head diameter, seed index, seed oil content and percentage of unfilled seeds. Also, Anwar et. al., (1995) reported that all sunflower yield components were affected by the number of irrigations.

Vitamins have vital importance on plant growth, they help plants to grow by providing them with essential nutrients. They also improve their immunity against plant diseases. Application of vitamins is accompanied by enhancing alpha keto glutaric acid biosynthesis which is united with ammonia to form amino acids and proteins, controlling the incidence of disorders and stimulating the biosynthesis of natural hormones like IAA, cytokinins and gibberellins, cell division, plant pigments, enzymes, organic foods and plant metabolism (Oretili, 1987 and Samiullah et al.,
1988). Vitamins have antioxidant properties which play a vital role in plant defense against oxidative stresses induced by unfavorable conditions.

Ascorbic acid (vitamin C) is an essential compound for plant tissues as it has antioxidant function, acts as an enzymatic cofactor and a plant growth regulator (Gomez and Lajolo, 2008). Ascorbic acid plays an important role in different processes. Like, photosynthesis, photoprotection and cell expansion resistance to environmental stress (Nicholas and Wheeler, 2000). Ahlam and Mustaf, 2019 reported that ascorbic acid plays an important role in controlling the timing of flowering and aging.

$\alpha$-tocopherol (vitamin E) is a low molecular weight lipophilic antioxidant which protect membrane from oxidative damage (Hess 1993 and El Bassiouny et al. 2005).

Nicotinamide (vitamin B3) is a watersoluble vitamin, it is a part of vitamin B group. Nicotinamide is a well- characterized constituent of the pyridine dinucleotide coenzymes NADH and $\mathrm{NADPH}$, nicotinamide induces and regulates secondary metabolic accumulation and the manifestation of defense metabolism in plant (Berglund, 1994, Sadak et al, 2010 and Bayan, 2019).

This study is a trial to investigate the effect of different vitamins and irrigation intervals on the vegetative growth, flowering and some biochemical 


\section{Scientific Journal of Agricultural Sciences 2 (2): 1-8, 2020}

constituents of Helianthus annuus L. in an effort to produce plants with high quality and providing the amount of used irrigation water.

\section{MATERIALS AND METHODS}

This study was done at Antoniades Research Branch, Horticulture Research Institute, A.R.C. Alexandria, Egypt, during the two successive seasons of 2017 and 2018.
Three weeks uniform sunflower seedlings were transplanted to plastic pots of $25 \mathrm{~cm}$ diameter using a mixture of sandy and clay soil at the ratio of $1: 1$ by volume on the $5^{\text {th }}$ of April 2017 and the $11^{\text {th }}$ of April 2018 in the first and second season respectively. The chemical analysis of the used medium is presented in Table (a).

Table a. Chemical analysis of the used mixture soil for the two growing seasons.

\begin{tabular}{lllllllll}
\hline \multirow{2}{*}{$\mathbf{p H}$} & \multirow{2}{*}{$\begin{array}{l}\mathbf{E C} \\
\mathbf{d s} / \mathbf{m}\end{array}$} & \multicolumn{2}{l}{ Cations (meq/l) } & \multicolumn{5}{c}{ Anions (meq/l) } \\
\cline { 3 - 8 } & & $\mathbf{C a}^{++}$ & $\mathbf{M g}^{++}$ & $\mathbf{N a}^{+}$ & $\mathbf{K}^{+}$ & $\mathbf{H C O}_{3}{ }^{-}$ & $\mathbf{C l}^{-}$ & $\mathbf{S O}_{4}^{--}$ \\
\hline $\mathbf{7 . 9 5}$ & $\mathbf{1 . 6 0}$ & 1.50 & 0.80 & 1.60 & 0.59 & 1.06 & 1.25 & 0.98 \\
\hline
\end{tabular}

Two irrigation intervals treatments i.e. every 2 or 3 days were used combined with four vitamins treatments i.e. control, ascorbic acid (vitamin $\mathrm{C}), \alpha-$ tocopherol (vitamin E) or nicotinamide (vitamin B3) producing ( $2 \times 4=8$ treatments).

After one week from the transplanting date on the $12^{\text {th }}$ of April 2017 and the $18^{\text {th }}$ of April 2018 (in the first and second seasons, respectively) similar plants in shapes were arranged into the experiment and the irrigation treatments were started. Plants were irrigated till $100 \%$ of the filed capacity of the used soil every 2 or 3 days. On the $13^{\text {th }}$ of April 2017 and the 19 ${ }^{\text {th }}$ of April 2018 (in the first and second seasons, respectively) freshly prepared solutions of ascorbic acid (vitamin C), $\alpha$-tocopherol (vitamin E) or nicotinamide (vitamin B3) at 100 ppm were prepared and sprayed with hand sprayer until the plants were wet to run off and control plants were sprayed with distilled water. The vitamins treatments repeated three times at two weeks intervals. All plants received normal fertilization of this plant. On the $2^{\text {nd }}$ of July 2017 and $10^{\text {th }}$ of July 2018 (in the first and second seasons, respectively) the experiment was terminated.

\subsection{The following data were measured in both of the two growing seasons:}

\subsubsection{Vegetative growth:}

Plant height $(\mathrm{cm})$, leaves number, leaf area/plant according to Zidan, 1962 . $\left(\mathrm{cm}^{2}\right)$, stem diameter $(\mathrm{cm})$, leaves dry weight $(\mathrm{g})$, and stem dry weight $(\mathrm{g})$.

\subsubsection{Flowering characteristics:}

Flowering date (days), flower duration (days), flower diameter $(\mathrm{cm})$ and flower dry weight $(\mathrm{g})$.

\subsubsection{Leaves chemical analysis:}

Chlorophyll a and b content ( $\mathrm{mg} / 100 \mathrm{~g}$ fresh weight) was determined according to Moran (1982), total carbohydrate content (\%) according to (Hedge and
Hofreiter 1962) and proline content ( $\mu \mathrm{g} / \mathrm{g})$ according to Bates et al. (1973).

The experiment layout was designed to provide complete randomized block design in factorial experiment, which contained three replicates, each replicate contained eight treatments. four pots were used as an experimental unit for each treatment in each replicate. The means of the individual factors and their interactions were compared by L.S.D test at 5\% level of probability according to Snedecor and Cochran (1989).

\section{RESULTS}

\subsection{Vegetative growth characteristics:}

\subsubsection{Effect of vitamins:}

Application of vitamins treatments significantly affected all studied sunflower traits in 2017 and 2018 seasons (Tables 1 and 2). Data presented in Table (1) showed that all vitamins treatments have a significant increase in plant height, number of leaves per plant and leaf area per plant compared with the control in both seasons. Generally, data in the two experimental seasons indicated that, $\alpha$-tocopherol caused the highest increase in plant height $(94.65$ and $109.11 \mathrm{~cm})$, number of leaves per plant (25.11 and 30.03) and leaf area per plant (515.79 and 629.83) in the first and second seasons, respectively compared to the other treatments. Also, data in Table (2) cleared that application of any vitamin significantly increased the stem diameter, leaves and stem dry weight compared to the control. The highest increase in stem diameter $(0.96$ and $1.08 \mathrm{~cm})$, leaves dry weight (7.06 and $8.84 \mathrm{~g}$ ) and stem dry weight (10.11 and $12.66 \mathrm{~g})$ in the both seasons, respectively were obtained with foliar spray of $\alpha$-tocopherol at 100 ppm. 
Table 1. Means of the plant height (cm), number of leaves and leaf area/plant $\left(\mathrm{cm}^{2}\right)$ of Helianthus annuus $L_{\text {. }}$, as influenced by the interaction between foliar spray of different vitamins and different irrigation intervals during the two successive seasons of 2017 and 2018.

\begin{tabular}{|c|c|c|c|c|c|c|c|}
\hline \multicolumn{2}{|c|}{ Treatments } & \multicolumn{2}{|c|}{ Plant height $(\mathrm{cm})$} & \multicolumn{2}{|c|}{ Number of leaves } & \multicolumn{2}{|c|}{ Leaf area/plant $\left(\mathrm{cm}^{2}\right)$} \\
\hline $\begin{array}{l}\text { Irrigation } \\
\text { intervals } \\
\text { (I) }\end{array}$ & $\begin{array}{l}\text { Vitamins } \\
\text { Type (V) }\end{array}$ & 2017 & 2018 & 2017 & 2018 & 2017 & 2018 \\
\hline \multirow{4}{*}{2 days } & Control & 78.67 & 95.83 & 18.83 & 24.11 & 375.20 & 473.28 \\
\hline & Ascorbic & 86.17 & 103.22 & 20.00 & 25.94 & 390.00 & 550.66 \\
\hline & $\alpha$-tocopherol & 88.22 & 104.33 & 24.00 & 29.39 & 400.00 & 560.00 \\
\hline & Nicotinamide & 84.17 & 98.33 & 22.83 & 27.67 & 393.90 & 564.67 \\
\hline Mean & & 84.31 & 100.43 & 21.42 & 26.78 & 389.77 & 537.15 \\
\hline \multirow{4}{*}{3 days } & Control & 75.50 & 93.33 & 18.00 & 23.44 & 372.29 & 459.89 \\
\hline & Ascorbic & 90.78 & 101.00 & 21.89 & 26.50 & 414.62 & 526.85 \\
\hline & $\alpha$-tocopherol & 101.07 & 113.89 & 26.22 & 30.67 & 631.58 & 699.67 \\
\hline & Nicotinamide & 97.50 & 105.89 & 21.67 & 28.56 & 505.73 & 606.20 \\
\hline Mean & & 91.21 & 103.53 & 21.94 & 27.29 & 481.05 & 573.15 \\
\hline \multirow{4}{*}{ Mean of $(\mathbf{V})$} & Control & 77.08 & 94.58 & 18.42 & 23.78 & 373.74 & 466.59 \\
\hline & Ascorbic & 88.47 & 102.11 & 20.94 & 26.22 & 402.31 & 538.76 \\
\hline & $\alpha$-tocopherol & 94.65 & 109.11 & 25.11 & 30.03 & 515.79 & 629.83 \\
\hline & Nicotinamide & 90.83 & 102.11 & 22.25 & 28.11 & 449.81 & 585.43 \\
\hline \multirow{3}{*}{ L.S.D. at 0.05} & I & N.S & N.S & N.S & N.S & 34.05 & 30.30 \\
\hline & $\mathrm{V}$ & 5.75 & 4.04 & 2.64 & 2.58 & 48.15 & 42.85 \\
\hline & V X I & 8.13 & 5.72 & N.S & N.S & 68.09 & 60.61 \\
\hline
\end{tabular}

L.S.D. at $0.05=$ Least significant different at 0.05 level of probability. $\quad$ N.S. $=$ not significant

Table 2. Means of the stem diameter (cm), leaves and stem dry weight (g) of Helianthus annuus L., as influenced by the interaction between foliar spray of different vitamins and different irrigation intervals during the two successive seasons of 2017 and 2018.

\begin{tabular}{|c|c|c|c|c|c|c|c|}
\hline \multicolumn{2}{|c|}{ Treatments } & \multicolumn{2}{|c|}{ Stem diameter $(\mathrm{cm})$} & \multicolumn{2}{|c|}{ leaves dry weight (g) } & \multicolumn{2}{|c|}{ Stem dry weight (g) } \\
\hline $\begin{array}{l}\text { Irrigation } \\
\text { intervals } \\
\text { (I) }\end{array}$ & $\begin{array}{l}\text { Vitamins } \\
\text { Type (V) }\end{array}$ & 2017 & 2018 & 2017 & 2018 & 2017 & 2018 \\
\hline \multirow{4}{*}{2 days } & Control & 0.76 & 0.78 & 5.15 & 5.27 & 7.03 & 8.07 \\
\hline & Ascorbic & 0.83 & 0.86 & 6.33 & 7.44 & 8.33 & 9.33 \\
\hline & $\alpha$-tocopherol & 0.93 & 1.05 & 6.38 & 8.33 & 9.50 & 11.99 \\
\hline & Nicotinamide & 0.84 & 0.93 & 6.10 & 7.06 & 9.05 & 11.18 \\
\hline Mean & & 0.84 & 0.90 & 5.99 & 7.03 & 8.48 & 10.14 \\
\hline \multirow{4}{*}{3 days } & Control & 0.74 & 0.76 & 4.40 & 4.82 & 6.83 & 7.78 \\
\hline & Ascorbic & 0.84 & 0.89 & 7.22 & 8.07 & 8.41 & 11.33 \\
\hline & $\alpha$-tocopherol & 1.00 & 1.10 & 7.75 & 9.35 & 10.73 & 12.99 \\
\hline & Nicotinamide & 0.87 & 0.97 & 6.90 & 8.30 & 9.29 & 12.35 \\
\hline Mean & & 0.86 & 0.93 & 6.57 & 7.63 & 8.81 & 11.11 \\
\hline \multirow{4}{*}{ Mean of (V) } & Control & 0.75 & 0.77 & 4.77 & 5.04 & 6.93 & 7.93 \\
\hline & Ascorbic & 0.84 & 0.87 & 6.78 & 7.76 & 8.37 & 10.33 \\
\hline & $\alpha$-tocopherol & 0.96 & 1.08 & 7.06 & 8.84 & 10.11 & 12.49 \\
\hline & Nicotinamide & 0.86 & 0.95 & 6.50 & 7.68 & 9.17 & 11.76 \\
\hline \multirow{3}{*}{ L.S.D. at 0.05} & $\mathrm{I}$ & N.S & N.S & 0.44 & 0.36 & 0.28 & 0.74 \\
\hline & V & 0.09 & 0.11 & 0.62 & 0.51 & 0.40 & 1.04 \\
\hline & V X I & N.S & N.S & 0.88 & 0.72 & 0.56 & 1.48 \\
\hline
\end{tabular}

L.S.D. at $0.05=$ Least significant different at 0.05 level of probability. $\quad$ N.S. $=$ not significant 


\subsubsection{Effect of irrigation intervals:}

Data in Tables (1) indicated that, applying the 3 days irrigation intervals gave a significant increase in leaf area per plant (481.05 and 573.15 $\mathrm{cm}^{2}$ ) during the two seasons, respectively compared with the 2 days intervals. However, there were insignificant difference between using either the two irrigation intervals on plant height and number of leaves during the two seasons. In addition, Tables (2) showed that, the 3 days irrigation intervals cause a significant increase in leaves Dry weight (6.57 and $7.63 \mathrm{~g})$ and stem dry weight (8.81 and $11.11 \mathrm{~g})$ in the first and second seasons, respectively compared to the 2 days intervals. On the contrary, using any of the two irrigation intervals did not cause a significant difference in stem diameter during the two experimental seasons.

\subsubsection{The interaction between vitamins and irrigation intervals:}

The interaction effect of irrigation intervals with the treatments of vitamin are presented in Table (1 and 2). The recording data showed that using the experimental vitamins could promote the vegetative growth of plants which are watered every 2 or 3 days compared with zero vitamin treatments. We observe that no usage of vitamins led to decrease in growth parameters with increasing the irrigation intervals. The highest significant increase of plant height $(101.07$ and $113.89 \mathrm{~cm})$, leaf area $(631.58$ and $\left.699.67 \mathrm{~cm}^{2}\right)$, leaves dry weight $(7.75$ and $9.39 \mathrm{~g})$ and stem dry weight (10.73 and $12.99 \mathrm{~g})$ in both seasons were obtained with using 3 days irrigation intervals combined with $\alpha$-tocopherol at $100 \mathrm{ppm}$. The statistical analysis of the obtained data of number of leaves and stem diameter were not great enough to reach the level of significant at 5\%.

\subsection{Flowering characteristics:}

\subsubsection{Effect of vitamins:}

Table (3) showed that different vitamins treatments caused a significant difference in flowering starting date (day), flower duration (day), flower diameter $(\mathrm{cm})$ and flower dry weight $(\mathrm{g})$ of sunflower plants comparing with the control treatment in both seasons. Moreover, using of the ascorbic acid gave the highest reduction in the time needed for flowering (80.28 and 85.67 day) and the maximum flower diameter $(10.71$ and $10.68 \mathrm{~cm})$, where, using of $\alpha$-tocopherol led to the highest flower duration (18.31and 17.97 day) and flower dry weight $(6.79$ and $7.40 \mathrm{~g})$ compared with the other treatments during the two seasons.

\subsubsection{Effect of irrigation intervals:}

Data presented in Tables (3) showed that the application of higher irrigation intervals (3days) resulted in the better all the flowering characters on sunflower plants than using the lower intervals (2days). The previous data were true in both experimental seasons. The statistical analysis of the obtained data reveals that flower duration (16.25 and 15.81day) and flower dry weight (6.271 and $6.66 \mathrm{~g}$ ) significantly increased by application of higher irrigation intervals (3days). On the other hand, these increase of flowering starting date (day) and flower diameter $(\mathrm{cm})$ did not reach the significant level.

\subsubsection{The interaction between vitamins and irrigation intervals:}

Regarding with the interaction of both factor's data in Table (3) found that, flowering characters of sunflower plants was significant effect except the flowering starting date and flower diameter. Generally, the obtained data in both seasons indicated that the highest significant increase in flower duration (20.28 and 19.33 day) and flower dry weight (7.73 and $7.93 \mathrm{~g}$ ) were recorded when plants sprayed by $\alpha$-tocopherol $(100 \mathrm{ppm})$ and irrigated every 3days as compared with the other interaction treatments.

\subsection{Chemical composition}

\subsubsection{Effect of vitamins:}

Table (4) cleared that application of any of the mentioned vitamins significantly increased chlorophyll a, chlorophyll $\mathrm{b}$ and total carbohydrate contents, also, it led to a significant decrease in proline concentration in plant leaves as compared to the control treatment. Generally, application of $\alpha$ tocopherol caused the highest increase in chlorophyll a (81.65 and $85.59 \mathrm{mg} / 100 \mathrm{~g})$, chlorophyll b (20.44 and $25.10 \mathrm{mg} / 100 \mathrm{~g})$ and total carbohydrate content (21.23 and $21.83 \%)$ and lowest concentration of proline (64.45 and 71.15 $\mu \mathrm{g} / \mathrm{g}$ ) in the two growing seasons.

\subsubsection{Effect of irrigation intervals:}

The results of Table (4) show that 3days irrigation intervals superiority over 2 days in the chlorophyll a (77.64 and $80.72 \mathrm{mg} / 100 \mathrm{~g})$ and chlorophyll b (19.72 and $22.96 \mathrm{mg} / 100 \mathrm{~g})$ in the leaves of plant, furthermore, it decreased the concentration of proline $(74.77$ and $79.82 \mu \mathrm{g} / \mathrm{g})$ in both experimental seasons. But, the increase of total carbohydrate did not reach the significant level. 
Table 3. Means of the flowering starting date (days), flower duration (days), flower diameter (cm) and flower dry weight (g) of Helianthus annuus $\mathrm{L}$., as influenced by the interaction between foliar spray of different vitamins and different irrigation intervals during the two successive seasons of 2017 and 2018.

\begin{tabular}{|c|c|c|c|c|c|c|c|c|c|}
\hline \multicolumn{2}{|c|}{ Treatments } & \multicolumn{2}{|c|}{$\begin{array}{ll}\text { Flowering } & \text { starting } \\
\text { date (days) } & \\
\end{array}$} & \multirow{2}{*}{$\begin{array}{l}\begin{array}{l}\text { Flower } \\
\text { (days) }\end{array} \\
2017\end{array}$} & \multirow{2}{*}{$\begin{array}{c}\text { duration } \\
2018\end{array}$} & \multicolumn{2}{|c|}{$\begin{array}{l}\text { Flower diameter } \\
(\mathrm{cm})\end{array}$} & \multicolumn{2}{|c|}{$\begin{array}{l}\text { Flower } \\
\text { weight (g) }\end{array}$} \\
\hline $\begin{array}{l}\text { Irrigation } \\
\text { intervals } \\
\text { (I) } \\
\end{array}$ & $\begin{array}{l}\text { Vitamins } \\
\text { Type (V) }\end{array}$ & 2017 & 2018 & & & 2017 & 2018 & 2017 & 2018 \\
\hline \multirow{4}{*}{2 days } & Control & 95.06 & 95.22 & 13.06 & 12.83 & 8.68 & 9.14 & 4.56 & 5.40 \\
\hline & Ascorbic & 77.89 & 86.44 & 16.12 & 16.28 & 10.62 & 10.68 & 5.90 & 6.65 \\
\hline & $\alpha$-tocopherol & 84.56 & 85.00 & 16.33 & 16.61 & 9.30 & 10.45 & 5.85 & 6.87 \\
\hline & Nicotinamide & 82.22 & 84.33 & 16.00 & 15.56 & 9.68 & 9.95 & 5.67 & 6.21 \\
\hline Mean & & 84.93 & 87.75 & 15.38 & 15.32 & 9.57 & 10.06 & 5.50 & 6.28 \\
\hline \multirow{4}{*}{3 days } & Control & 95.67 & 97.22 & 12.83 & 12.22 & 8.50 & 8.45 & 4.50 & 5.08 \\
\hline & Ascorbic & 82.67 & 84.89 & 16.89 & 16.56 & 10.80 & 10.68 & 6.63 & 7.31 \\
\hline & $\alpha$-tocopherol & 84.67 & 89.67 & 20.28 & 19.33 & 10.00 & 9.67 & 7.73 & 7.93 \\
\hline & Nicotinamide & 86.33 & 89.33 & 15.00 & 15.11 & 8.94 & 10.01 & 6.21 & 6.33 \\
\hline Mean & & 87.33 & 90.28 & 16.25 & 15.81 & 9.56 & 9.70 & 6.27 & 6.66 \\
\hline \multirow{4}{*}{ Mean of (V) } & Control & 95.36 & 96.22 & 12.94 & 12.53 & 8.59 & 8.80 & 4.53 & 5.24 \\
\hline & Ascorbic & 80.28 & 85.67 & 16.51 & 16.42 & 10.71 & 10.68 & 6.26 & 6.98 \\
\hline & $\alpha$-tocopherol & 84.61 & 87.33 & 18.31 & 17.97 & 9.65 & 10.06 & 6.79 & 7.40 \\
\hline & Nicotinamide & 84.28 & 86.83 & 15.50 & 15.33 & 9.31 & 9.98 & 5.94 & 6.27 \\
\hline \multirow{3}{*}{ L.S.D. at 0.05} & I & N.S & N.S & 0.65 & 0.38 & N.S & N.S & 0.38 & 0.27 \\
\hline & $\mathrm{V}$ & 6.19 & 3.23 & 0.92 & 0.54 & 0.71 & 0.79 & 0.54 & 0.38 \\
\hline & V X I & N.S & N.S & 1.30 & 0.76 & N.S & N.S & 0.76 & 0.54 \\
\hline
\end{tabular}

L.S.D. at $0.05=$ Least significant different at 0.05 level of probability.

N.S. $=$ not significant

Table 4. Means of the chlorophyll a, b (mg/100g leaves fresh weight), total carbohydrate (\%) and proline concentration $(\mu \mathrm{g} / \mathrm{g})$ of Helianthus annuus $\mathrm{L}$., as influenced by the interaction between foliar spray of different vitamins and different irrigation intervals during the two successive seasons of 2017 and 2018.

\begin{tabular}{|c|c|c|c|c|c|c|c|c|c|}
\hline \multicolumn{2}{|c|}{ Treatments } & \multicolumn{2}{|c|}{$\begin{array}{c}\text { chlorophyll a } \\
\text { (mg/100g leaves } \\
\text { fresh weight) }\end{array}$} & \multicolumn{2}{|c|}{$\begin{array}{c}\text { chlorophyll b } \\
\text { (mg/100g leaves } \\
\text { fresh weight) }\end{array}$} & \multicolumn{2}{|c|}{$\begin{array}{c}\text { Total } \\
\text { carbohydrate } \\
(\%) \\
\end{array}$} & \multicolumn{2}{|c|}{$\begin{array}{c}\text { Proline } \\
\text { concentration } \\
(\mu \mathrm{g} / \mathrm{g}) \\
\end{array}$} \\
\hline $\begin{array}{l}\text { Irrigation } \\
\text { intervals } \\
\text { (I) }\end{array}$ & $\begin{array}{l}\text { Vitamins } \\
\text { Type (V) }\end{array}$ & 2017 & 2018 & 2017 & 2018 & 2017 & 2018 & 2017 & 2018 \\
\hline \multirow{4}{*}{2 days } & Control & 51.14 & 60.91 & 12.41 & 17.47 & 14.33 & 14.49 & 107.97 & 109.96 \\
\hline & Ascorbic & $68.52 b$ & 72.52 & 17.17 & 18.52 & 18.67 & 19.72 & 96.06 & 97.06 \\
\hline & $\alpha$-tocopherol & 73.18 & 80.15 & 18.03 & 22.80 & 20.17 & 21.00 & 67.82 & 77.33 \\
\hline & Nicotinamide & 69.47 & 82.67 & 17.48 & 23.70 & 18.61 & 19.95 & 78.71 & 83.61 \\
\hline Mean & & 65.58 & 74.06 & 16.27 & 20.62 & 17.95 & 18.79 & 87.64 & 91.99 \\
\hline \multirow{4}{*}{3 days } & Control & 47.07 & 57.73 & 11.98 & 14.49 & 14.00 & 14.05 & 102.17 & 111.67 \\
\hline & Ascorbic & 88.58 & 88.21 & 22.72 & 24.97 & 21.38 & 22.51 & 70.51 & 72.54 \\
\hline & $\alpha$-tocopherol & 90.12 & 91.04 & 22.84 & 27.39 & 22.30 & 22.67 & 61.08 & 64.97 \\
\hline & Nicotinamide & 84.77 & 85.90 & 21.36 & 24.97 & 18.33 & 18.68 & 65.31 & 70.09 \\
\hline Mean & & 77.64 & 80.72 & 19.72 & 22.96 & 19.00 & 19.48 & 74.77 & 79.82 \\
\hline \multirow{4}{*}{$\begin{array}{l}\text { Mean of } \\
\text { (V) }\end{array}$} & Control & 49.10 & 59.32 & 12.20 & 15.98 & 14.17 & 14.27 & 105.07 & 110.81 \\
\hline & Ascorbic & 78.55 & 80.36 & 19.95 & 21.74 & 20.02 & 21.12 & 83.29 & 84.80 \\
\hline & $\alpha$-tocopherol & 81.65 & 85.59 & 20.44 & 25.10 & 21.23 & 21.83 & 64.45 & 71.15 \\
\hline & Nicotinamide & 77.12 & 84.28 & 19.42 & 24.34 & 18.47 & 19.32 & 72.01 & 76.85 \\
\hline \multirow{3}{*}{$\begin{array}{l}\text { L.S.D. at } \\
0.05\end{array}$} & I & 4.49 & 3.10 & 2.73 & 1.54 & N.S & N.S & 14.49 & 14.10 \\
\hline & V & 6.35 & 4.38 & 3.87 & 2.17 & 2.13 & 1.19 & 10.25 & 9.97 \\
\hline & V X I & 8.98 & 6.20 & 5.47 & 3.07 & 3.01 & 1.69 & N.S & N.S \\
\hline
\end{tabular}

L.S.D. at $0.05=$ Least significant different at 0.05 level of probability. $\quad$ N.S. $=$ not significant 


\subsubsection{The interaction between vitamins and irrigation intervals:}

Table (4) show that there were significant effects due to the interaction between application of different vitamins and irrigation intervals on the chlorophyll a, b and total carbohydrate content during the two seasons, compared to the control treatment. While, there was no significant effect on proline concentration in the first and second seasons. In addition, we observe that a negative effect on the all chemical composition in case of no usage of vitamins with increasing the irrigation intervals. Anyway, using of $\alpha$-tocopherol combined with 3days irrigation intervals gave the highest leaves content of chlorophyll a (90.12 and $91.04 \mathrm{mg} / 100 \mathrm{~g})$, chlorophyll b (22.84 and $27.39 \mathrm{mg} / 100 \mathrm{~g})$ and total carbohydrate $(22.30$ and $22.67 \%)$ during the two seasons respectively.

\section{DISCUSION}

\subsection{Vegetative growth characteristics:}

Our results highlighted that ornamental sunflower plants are able to grow well under irrigation intervals 2 or 3 days combine with vitamins compared with the zero vitamin treatments, especially, the plant height, leaf area, leaves and stem dry weight which are significant increased. These results may be due to vitamins accumulations occur in response to a variety of biotic stresses including high light, drought, salt and cold and may provide an additional line of protection from oxidative damage (Bosch, 1995). Also, this increment may be due to the enhancement of vitamins on cell division and /or cell enlargement (Mozafa and Oertli, 1992 and Arrigoni et al., 1997) and / or the influence DNA replication (Noctor and Foyer, 1998 and Bartoli et al., 1999).

The magnitude of increase is much more pronounced by applying $\alpha$-tocopherol. It could be concluded that $\alpha$-tocopherol is believed to protect chloroplast membranes from photo oxidation and help to provide an optimal environment for the photosynthetic machinery (Bosch, 1995). Similarly, $\alpha$-tocopherol induced growth improvement was reported in Vicia faba (Orabi and Abdelhamid, 2014; Semida et al., 2014), lettuce, Shafeek et. al., (2013) Calendula officinalis L (Soltani et al., 2012), geranium (Ayad et al., 2009) and Hibiscus rosasineses (El-Aziz et al., 2009) under stress conditions. They all attributed $\alpha$-tocopherol induced improvement in growth attributes to better water potential, high accumulation of antioxidants, less oxidative damage and better cross-talk among different growth regulators.
Reduction of plant size and growth under water stress may be attributed to a decrease in the activity of meristemic tissues responsible for elongation. As well as the inhibition photosynthetic efficiency under insufficient water condition (Siddique et al., 1999). Amal et.al., (2019) reported that water stress significantly decreased all characters of sesame yield and yield components.

\subsection{Flowering characteristics:}

Generally, results of the two seasons indicated that spraying of any vitamins at any irrigation intervals caused a significant increase in flower duration and dry weight compared with the zero vitamin treatments. Perhaps this may be due to the role of vitamins as co -enzyme in an enzymatic cofactor and plant growth regulator (Gomez and Lajolo, 2008). These findings are in agreement with those reported by El-Bassiouny et al. (2005), AlQubaie (2012) and Sadiq et al. (2017).

Also, the positive effect of ascorbic acid on flower characters may be due to Barth et al., (2004) who reported that the effects of ascorbic acid on flowering time could be related to alterations in phytohormone levels such as gibberellic acid, abscisic acid, salicylic acid and ethylene and that the redox status of ascorbic acid may play a role in signaling in this interconnected phytohormone network.

\subsection{Chemical composition}

The increase in photosynthetic pigments and carbohydrates content in sunflower leaves may be due to the role of antioxidants in protecting chloroplast membranes from photooxidation and help to provide an optimal environment for the photosynthetic machinery (Munné-Bosch and Alegre, 2002) and the vital roles of water supply at adequate amount for different physiological processes such as photosynthesis, respiration, transpiration, translocation, enzyme reaction and cells turgidity occurs simultaneously (El-Monayeri et al., 1983) and (Mona et al., 2000). These results are in agreement with those obtained by Hassanein et al. (2009) in maize when they used ascorbic acid and nicotinamide and Sadak et al. (2010) in sunflower when they used $\alpha$-tocopherol and nicotinamide.

All the vitamins significantly decrease leaves proline content compared to control treatment which may due to the role of vitamins in decease of plant stress.

\section{CONCLUSION}

Based on the results of this study, we recommend that application of $\alpha$ - tocopherol at 100 
ppm combined with 3 days irrigation intervals this treatment resulted the highest values of plant height, leaf area, leaves and stem dry weight, flower duration, flower dry weight, leaves chlorophyll content and total carbohydrate, besides, it saved the amount of irrigation water used in plant production by $33 \%$.

\section{REFERENCES}

Ahlam AH, Mustaf KI (2019). Responses of two varieties of Cucurbita pepo L. Planted Inside the Plastic Houses to foliar spraying of ascorbic acid. Plant Archives, 19 (1): 1768-1772.

Al-Qubaie AI (2012). Response of sunflowers cultivar Giza-102 (Helianthus annuus L.) plants to spraying some antioxidants. Nature and Science, 10 (11): 1-6.

Amal GA, Nabila MZ, Hassanein MS (2019). Effect of water regime and varietal differences on yield and its components of sesame. Middle East Journal of Applied Sciences, 9(4):914-918.

Anwar M, Rehman S, Khan S, Quarishi Z (1995). Response of sunflower varieties to different irrigation regimes during Kharif season in Peshawar Valley. Sarhad J. Agri., 11: 273-278.

Arrigoni O, Calabrese G, DeGara L, Brronti MB, Liso $R$ (1997). Correlation between changes in cell ascorbate and growth of Lupinus albus seedlings. J. Plant Physiol., 150:302-308.

Ayad HS, El-Din KG, Reda F (2009) Efficiency of stigmasterol and $\alpha$-tocopherol application on vegetative growth, essential oil pattern, protein and lipid peroxidation of geranium (Pelargonium graveolens L.). J. Appl. Sci. Res., 5:887-892.

Barth C, Moeder W, Klessig DF, Conklin PL (2004). The timing of senescence and response to pathogens is altered in the ascorbate-deficient Arabidopsis mutant vitamin c-1. Plant Physiol., 134:1784-1792

Bartoli CG, Somontacchi M, Tambussi E, Beltrano J, Montaldi E, Puntarulo S (1999). Drought and watering dependent oxidative stress: Effect on antioxidant content in Triticum aestivum $L$. leaves. J. Expt. Bot., 332:375-383.

Bates L, Waldern R, Teare I (1973). Rapid determination of free proline for water stress studies. Plant and Soil, 39:205-207.

Bayan HM (2019). Effect of ascorbic acid and nicotine amid spraying in tomato growth and productivity. Biochem. Cell. Arch., 19 (2): 28732876.

Berglund T (1994). Nicotinamide, a missing link in the early stress response in eukaryotic cells: A hypothesis with special reference to oxidative stress in plants. FEBS Lett., 351(2):375- 383.

Bosch SM (1995). The role of a-tocopherol in plant stress tolerance. J. Plant Physiol., 162: 743-748.
Cormenzana JMA (2001). El cultivo de girasol (Helianthus annuus) para flor cortada. Flormarket, 2: p.55-61.

El Bassiouny Hala MS, Gobarah ME, Ramadan AA (2005). Effect of antioxiants on growth, yieldand favism causative agents in seeds of Vicia faba L. plants grown under reclaimed sandy soil. Journal of Agronomy, 4(4): 281-287.

El-Aziz A, Nahed G, Kandil MM (2009). Some studies on the effect of ascorbic acid and alphatocopherol on the growth and some chemical composition of Hibiscus rosa sineses L. at Nubaria. Ozean J. Appl. Sci., 2(2): 159-167.

El-Monayeri MO, Hegazi M, Ezzat NH, Salem HM, Tahoun (1983). Growth and yield of some wheat and barley varieties grown under different moisture stress levels. Annals. Agric., Moshtohor., 20(3): 231-240.

Gomez ML, Lajolo FM (2008). Ascorbic acid metabolism in fruits: activity of enzymes involved in synthesis and degradation during ripening in mango and guava. J. Sci. Food and Agric., 88:756-762.

Hassanein RA, Bassony FM, Barakat DM, Khalil RR (2009). Physiological effects of nicotinamide and ascorbic acid on Zea mays plant grown under salinity stress. I - changes in growth, some relevant metabolic activities and oxidative defense systems. Res. J. Agric. Bio. Sci., 5(1):72-81.

Hedge JE, Hofreiter BT (1962). In: Carbohydrate Chemistry, 17 (Eds. Whistler R.L. and Be Miller, J.N.), Academic Press, New York.

Hess JL (1993). Vitamin E, á-Tocopherol. In: Antioxidants in higher plants. R.G. Alscher \& J.L. Hess (Eds.). CRC press, Inc., Boca Raton., 111-134.

Kakar AA, Soomro AG (2001). Effect of water stress on the growth, yield and oil content of sunflower. Pakistan Journal of Agricultural Sciences, 38: 73-74.

Kirtimala B, Naik B, Nataraj SK, Shadakshari YG, Kumar DP, Seetharamu GK (2018). Standardization of Optimum Stage of Harvest for Enhancing Vase Life in Ornamental Sunflower (Helianthus annuus L.). Int. J. Pure App. Bio. sci., 6 (4): 733-735.

Mona M Shehata, Sohair A Azer, Shafika N Mostafa (2000). The effect of soil moisture stress on some sugar beet varieties. Egypt J. Agric. Res., 78(3): 1141-1160.

Moran $R$ (1982). Formula determination of chlorophyll pigment extracted with N,N diethyl formamide . Plant Physiol., 69:1376-1381.

Mozafar A, Oertli JJ (1992). Uptake of microbially produced vitamin $\left(\mathrm{B}_{12}\right)$ by soybean roots. Plant and Soil, 139: 23-30.

Munné-Bosch S, Alegre L (2002). The function of tocopherols and tocotrienols in plants. Critical Reviews in Plant Sciences, 21(1):31-57. 
Nicholas S, Wheeler LW (2000). Ascorbic acid in plants: Biosynthesis and function. Curr. Rev. Plant Sci., 19(41):267- 290.

Noctor G, Foyer CH (1998). Ascorbate and glutathione keeping active oxygen under control. Annu. Rev. Plant Physiol. Plant Mol. Biol., 49:249279.

Orabi SA, Abdelhamid MT (2014). Protective role of $\alpha$-tocopherol on two Vicia faba cultivars against seawater-induced lipid peroxidation by enhancing capacity of anti-oxidative system. J. Saudi Soc. Agric. Sci., 15:145-154.

Oretili JJ (1987). Exogenous application of vitamins as regulators for growth and development of plants. Pflanzen Rahe Boden, 150:375-391.

Sadak M.S, Rady M, Badr NM, Gaballah MS (2010). Increasing sunflower salt tolerance using nicotinamide and $\alpha$-tocopherol. Int. J. Acad. Res., 2(4):263-270.

Sadiq M, Akram N, Ashraf M (2017). Foliar applications of alpha tocopherol improves the composition of fresh pods of Vigna radiate subjected to water deficiency. Turk. J. Bot., 41:244252.

Samiullah SA, Ansori MM, Afridi RK (1988). BVitamins in relation to crop productivity, Indian Rev. Life Sci., 8:51-74.
Semida WM, Taha RS, Abdelhamid MT, Rady MM (2014). Foliar-applied $\alpha$-tocopherol enhances salt-tolerance in Vicia faba L. plants grown under saline conditions. South Afr. J. of Bot., 95: 24-31.

Shafeek, MR, Helmy YI, Neama M. Marzauk Magda A.F. Shalaby, Nadia M. Omar (2013). Effect of foliar application of some antioxidants on growth, yield and chemical composition of Lettuce plants (Lactuca Sativa L.) under plastic house condition. Middle East J. of App. Sci., 3(2):70-75.

Siddique MR, Hamid B, Islam MS (1999). Drought stress effect on photosynthetic rate and leaf gas exchange of wheat. Bot. Bull. Acad. Sin., 40(20): 141-145.

Snedecor GW, Cochran W (1989). Statistical Methods, $8^{\text {th }}$ ed. Iowa State University Press.

Soltani Y, Saffari VR, Moud AAM, Mehrabani $M$ (2012). Effect of foliar application of $\alpha$ tocopherol and pyridoxine on vegetative growth, flowering, and some biochemical constituents of Calendula officinalis L. plants. Afr. J. Biotechno., 11(56): 11931-11935.

Zidan E (1962). Evaluation of some tomato lives of tomato in record to leaf area and leaf efficiency and relation of partial to early and total yield, fruit size, soluble solids, leaf rolling and blossom - end rot ph. D. thesis, Cornel Univ. Itacha N.Y., U.S.A.

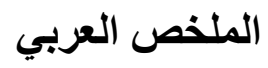

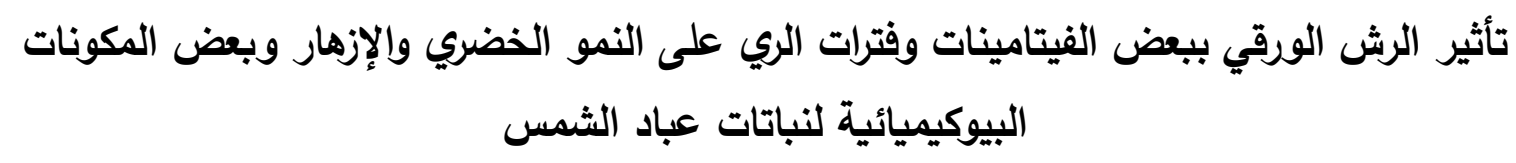

$$
\begin{aligned}
& \text { نجلاء محمد مصطفى } \\
& \text { فرع بحوث نباتات الزينة بانطونيادس - الإسكندرية - قسم بحوث نباتات الزينة وتتسيق الحدائق - معهد بحوث البساتين - مركز البحوث } \\
& \text { الزراعية - جمهورية مصر العربية. }
\end{aligned}
$$

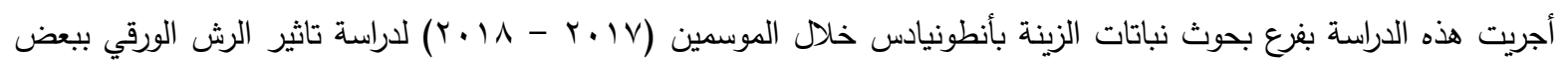

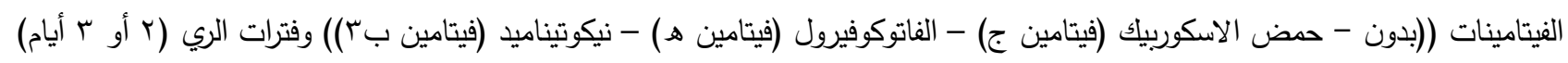

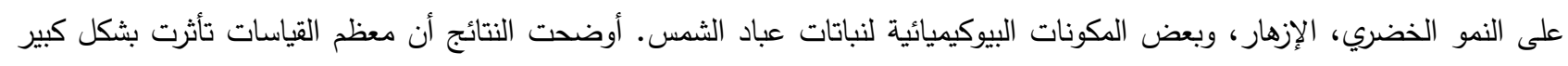

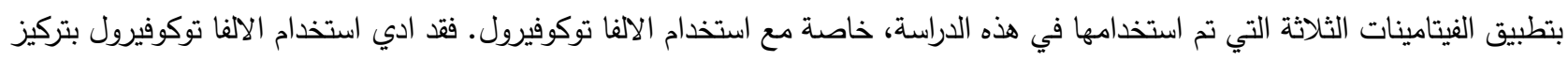

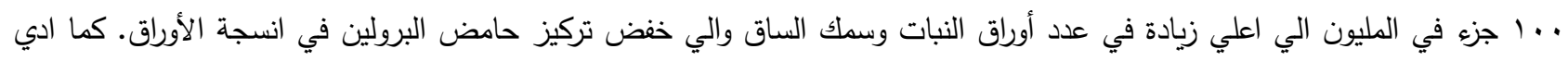

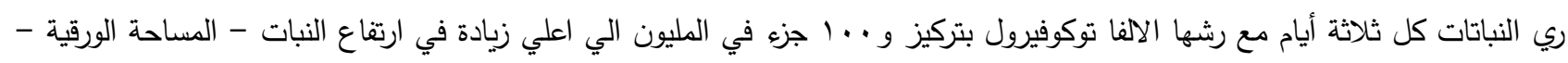

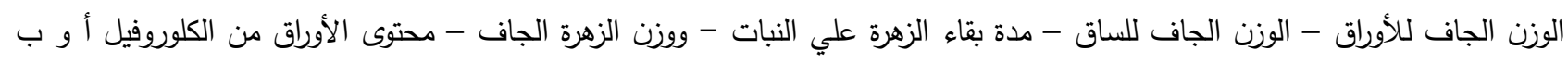

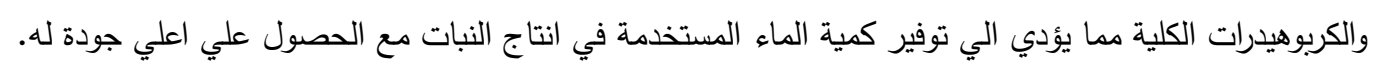

